\title{
Ruskeiden kananmunien kalanhaju historiaan
}

M. Honkatukia, ${ }^{1}$ K. Reese, ${ }^{2}$ R. Preisinger, ${ }^{3}$ M. Tuiskula-Haavisto, ${ }^{1}$ S. Weigend, ${ }^{2}$ J. Roito, ${ }^{1}$ A. MäkiTanila, ${ }^{1}$ and J. Vilkki ${ }^{1}$

${ }^{1}$ MTT Agrifood Research Finland, 31600 Jokioinen, Finland,

${ }^{2}$ Institute for Animal Breeding Mariensee (FAL), 31535 Neustadt, Germany,

${ }^{3}$ Lohmann Tierzucht GmbH, Cuxhaven, Germany.

\section{Tiivistelmä}

Ruskeissa kananmunissa esiintyvä kalanhaju on aiheuttanut mittavia ongelmia niin kananjalostukselle, tuottajille kuin kaupallekin. Ongelma koskettaa erityisesti eurooppalaisia kuluttajia, sillä EU-alueella yli 90\% kulutetuista munista on ruskeita. Suomessa ongelma on toistaiseksi ollut marginaalinen, sillä kulutustottumukset ovat suosineet valkoisia munia, ruskeiden myyntiosuuden jäädessä alle kymmeneen prosenttiin.

Kuluttajan näkökulmasta ongelma kärjistyy ruoanlaitossa: hajun on toisinaan havaittu voimistuvan käsiteltäessä munia kuten esimerkiksi keitettäessä tai paistettaessa. Kaupan laadunvalvonnan satunnaistesteistä löydetyt kalanhajuiset munat voivat johtaa koko sisäänostoerän hylkäämiseen. Pahimmassa tapauksessa tuottaja joutuu vaihtamaan koko kanalansa tuotantoeläimet muutaman haisevan munan takia.

Hajun aiheuttava geeni tunnistettiin geenikartoituksen avulla. Taustalla on geenivirhe, joka johtaa hajuhaittaan, kuitenkin vain yhdessä tietynlaisen, yleensä rypsi- tai rapsipohjaisen ruokinnan kanssa. Valkoisilta kanoilta tämä geenivirhe puuttuu. Ruskeidenkaan kanojen munat eivät haise, elleivät geenivirheen perineet kanat ole saaneet rehua, joka sisältää hajun aiheuttajaa. Yleensä noin noin 5-10 prosenttia ruskeista kanoista voi tuottaa haisevia munia.

Perinteisesti DNA-tutkimuksiin on vaadittu verinäytettä, jonka ottaminen voi pahimmillaan olla kanalle stressaava ja kivulias kokemus. Sen sijaan on mahdollista käyttää testauksessa höyheniä: jo yhdessä höyhentupessa on riittävä määrä DNA:ta, josta testi voidaan tehdä. Geenivirheen testaamiseksi onkin kehitetty höyhenestä tehtävä nopea ja yksinkertainen laboratoriomenetelmä. Menetelmän ansiosta voidaan ruskeita kanalinjoja valita risteytettäviksi niin, ettei jälkeläisissä ilmene hajuhaittaa aiheuttavaa geenivirhettä.

Testausmenetelmälle on haettu kansainvälistä patenttia. Tällä menetelmällä jalostettujen kanalinjojen markkinointi aloitetaan vuoden lopussa ja ensimmäiset hajuttomat untuvikot ovat myynnissä elokuussa 2006. Nämä kanat aloittavat munintansa vuoden 2007 alussa. Testin ansiosta luomutuotannossa on mahdollista käyttää rehun valkuaislähteinä kotimaista rypsiä ja rapsia, mahdollisesti siirryttäessä 100 \%:n luomuruokintaan.

Avainsanat: Kananmuna, kalanhaju, geenikartoitus, geenitesti. 


\section{Johdanto}

Vastamunitut munat voivat toisinaan haista mädäntyneelle kalalle. Erityisesti ongelma vaivaa ruskeita munijalinjoja. Ongelmaa on tutkittu 1970-luvulta lähtien, joilloin munijakanojen rehuun alettiin lisätä rypsirouhetta ja hajua alkoi ilmetä. Koska hajuhaittaa esiintyi erityisesti ruskeilla munijalinjoilla, syntyi virheellinen johtopäätös kalanhajun ja kuorenvärin kytkennästä. Myöhemmin osoitettiin, että haju johtuu kuorenväristä riippumattomasta perintötekijästä; aiheuttaja oli keltuaisen sisältämä ylenmääräinen trimetyyliamiini (TMA) -yhdiste.

Hajuoireyhtymästä eivät kärsi yksinomaan kanat; sitä tavataan myös ihmisiltä ja lehmältä. Ihmisillä oireet ilmenevät kehon eritteiden, kuten hien, syljen ja virtsan epämiellyttävänä hajuna. Oireyhtymää kantavat lehmät puolestaan voivat erittää maitoonsa kalanhajua ja -makua.

Normaalisti maksan entsyymi, mono-oksygenaasi (flavin containing mono-oxygenase 3, FMO3) katalysoi elimistössä olevan trimetyyliamiinin hapettumisreaktiota hajuttomaksi yhdisteeksi, joka poistuu eritteiden mukana elimistöstä. Ihmisellä ja lehmällä kalanhaju -syndrooman syyksi on osoitettu FMO3 -geenin muutokset, jotka johtavat siihen että eritteisiin päätyy hapettamatonta TMA:ta, jolle on ominaista mädän kalan haju. Tämän tutkimuksen tavoitteena oli selvittää saman geenin osuutta tuoreiden kananmunien kalanhajuun geenikartoituksen avulla.

\section{Aineisto ja menetelmät}

Haju-ominaisuuden ja FMO3-geenin kytkentäkartoitus tehtiin kahdessa toisistaan riippumattomassa puolisisarusaineistossa. Ensimmäiseen kartoituspopulaatioon kuului 5 puolisisarusperhettä, täyssisarusten lukumäärien vaihdellessa 90 ja 120 välillä. Aineistossa tehtiin koko genomin kattava kytkentäkartoitus. Geneettisinä markkereina käytettiin 119 mikrosatelliittimarkkeria 25:stä eri kytkentäryhmästä.

Haju-fenotyyppiä tutkittiin kahden viikon ruokintakokeen jälkeen. Ruokintakokeessa munivien kanojen rehuun oli lisätty $10 \%$ rypsirouhetta. Arvioiminen tapahtui aistinvaraisesti rikotuista munista.

Ensimmäisessä kartoitusvaiheessa käytettiin DNA-poolinäytteitä, jolloin yhdestä puolisisarusperheestä tuli analysoitavaksi kaksi näytettä fenotyyppijakauman ääripäistä: haisevat ja normaalit. Poolianalyysilla etsittiin alueita genomista, joissa näkyy isän markkerialleelien jakaumien vinoutuneisuus vastakkaisten (haju/normaali) poolinäytteiden välillä. Tutkimus eteni tyypittämällä perheitä yksilötasolla poolianalyysin tulosten osoittamassa kohdassa genomia.

Toinen kartoituspopulaatio koostui $450 \quad \mathrm{~F}_{2}$-kanasta. Sitä käytettiin sekä kytkentätulosten vahvistamiseksi että TMA:n assosiaatioanalyysiin. Tästä populaatiosta haju määritettiin biokemiallisesti mittaamalla TMA-pitoisuutta.

Markkerigenotyypitysten ohella sekvensoitiin kandidaattigeeniä (FMO3; flavin containing mono-oxygenase 3). Sekvensensoinnissa etsittiin haisevien ja normaalien yksilöiden väliltä DNAtason eroavaisuuksia. Sekvensointi tuotti useita yhden emäksen eroja DNA-tasolla (SNP, single nucleotide polymorphism). Yhtä näistä SNP-kohdista käytettiin geneettisenä markkerina kytkentäanalyysissa.

\section{Tulokset}

Poolien jakaumien vinoutta löytyi usean kytkentäryhmän (GGA4, GGA7, GGA8 ja E46C08W18) yksittäisistä markkereista. Ainoastaan kromosomi 8:n (GGA8) tulokset näyttivät olevan johdonmukaisia verrattaessa vierekkäisiä markkereita eri perheissä. Tämän perusteella kytkentäanalyysiä jatkettiin tässä kromosomissa. Kaikki yksilöt tyypitettiin neljällä mikrosatelliittimarkkerilla (MCW0275, ADL0322, LEI0179, MCW0305) ja kandidaattigeenin FMO3 SNP-markkkerilla viidessä perheessä. Kartoituksen avulla paikannettiin FMO3 -geeni kromosomiin 8. Samoin voitiin osoittaa, että hajuoireella oli tiivis kytkentä kandidaattigeeniin. 


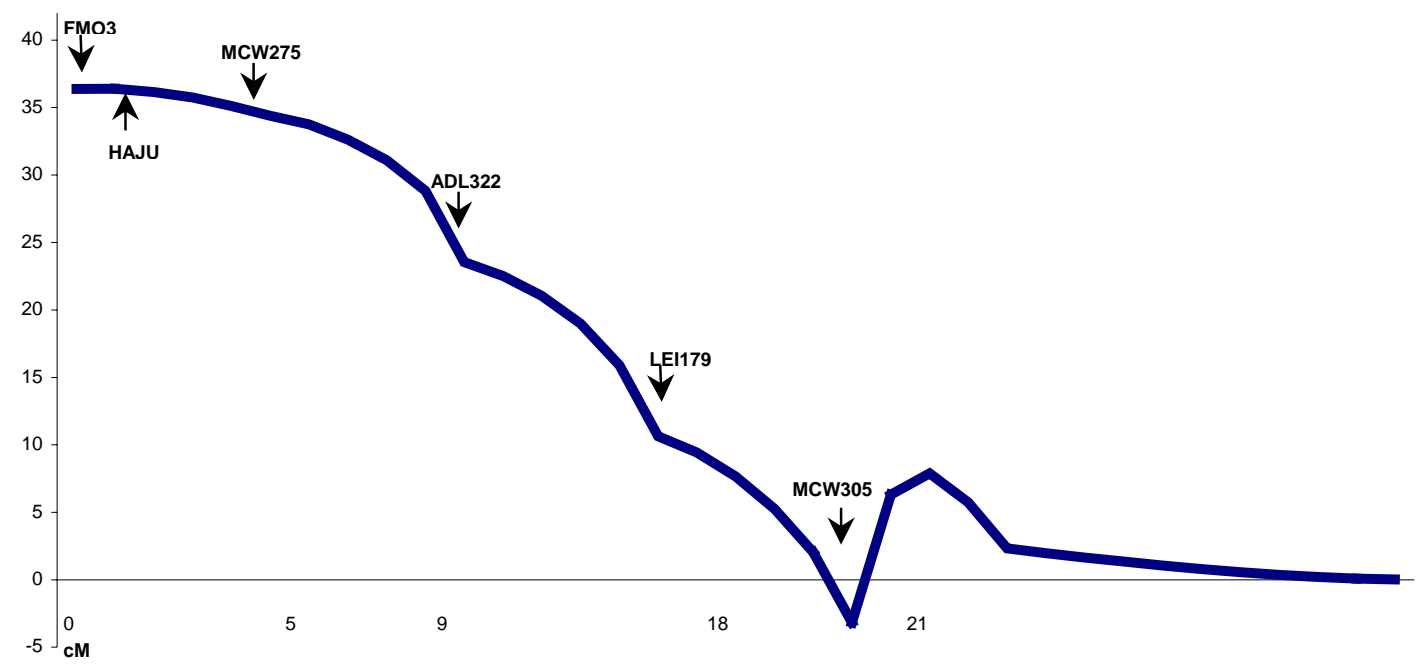

Kuva 1. Kytkentäkartta kromosomista 8. Kartoittamisessa käytettiin neljää mikrosatelliittimarkkeria (MCW275, ADL322, LEI179 ja MCW305) sekä yhtä SNP-markkeria FMO3 -geenistä (FMO3). Haju kartoitettiin assosiaatioanalyysin avulla kytkentäkartalle.

Kytkentäanalyysin tulokset varmistettiin riippumattomassa tutkimusaineistossa. Tästä aineistosta saatiin hajulle luotettava biokemiallinen määritys keltuaisen TMA-pitoisuutena.

Sekvensoinnin tuloksena havaittiin 17 eroavaisuutta haisevien ja normaalien yksilöiden väliltä. Yhdeksän muutoskohtaa osuu geenin koodaavalle alueelle, mutta vain yksi eroavaisuus johtaa aminohappomuutokseen. Muutos T329S sijaitsee FMO3-proteiinin hyvin konservoituneella (ns. FATGY -motif) alueella, joka on säilynyt evoluution aikana samanlaisena mono-oksygenaasin kaltaisissa proteiineissa aina bakteereista ihmiselle (Kuva 2). Sama muutos havaittiin kaikissa kolmessa tutkitussa ruskeassa munijakanalinajssa (Tetra, Isa Brown, Lohmann Brown). Alleeli S esiintyi homotsygoottina kaikissa kanoissa, joiden munissa oli havaittu korkea TMA-pitoisuus, eikä koskaan kanoissa, joiden munat eivät haisseet rypsiruokinnan jälkeen.

Taulukko 1. T329 mutaation yleisyys eri kanapopulaatioissa: kaupallisilla ruskeilla munijalinjoilla (Isa Brown, Lohmann Brown, TETRA) ja muutamassa erikoispopulaatiossa (Marans, puolalainen ja islantilainen maatiaiskana, transylvanialainen kana).(S=haiseva)

\begin{tabular}{|l|c|c|c|}
\hline & \multirow{2}{*}{$\mathrm{N}$} & \multicolumn{2}{|c|}{ Alleelifrekvenssi } \\
\cline { 3 - 4 } & & $\mathrm{T}$ & $\mathrm{S}$ \\
\hline Viidakkokana (Gallus gallus gallus) & 10 & 1.00 & 0.00 \\
\hline Fayoumi & 10 & 1.00 & 0.00 \\
\hline puolalainen maatiaiskana (green-legged partridge) & 8 & 0.81 & 0.19 \\
\hline islantilainen maatiaiskana & 10 & 1.00 & 0.00 \\
\hline ISA Brown & 71 & 0.58 & 0.42 \\
\hline Lohmann Brown & 67 & 0.62 & 0.38 \\
\hline Marans & 111 & 0.96 & 0.04 \\
\hline TETRA & 70 & 0.61 & 0.39 \\
\hline Transsylvanialainen kana (transylvanian naked-neck) & 8 & 0.69 & 0.31 \\
\hline
\end{tabular}


Kuva 2. FMO -proteiiniperheen sekvenssilinjaus aminohappomuutoskohdassa T329S (-faTgy-). Proteiinin nimi ja eliölaji on esitetty vasemmalla, oikealla 20 aminohapon mittainen sekvenssi mutaatiokohdan ympäriltä. Konservoitumisastetta kuvaavat värikoodit; mustalla merkitty aminohappo esiintyy jokaisella eliölajissa, harmaa $>80$ \%:lla eliöistä.
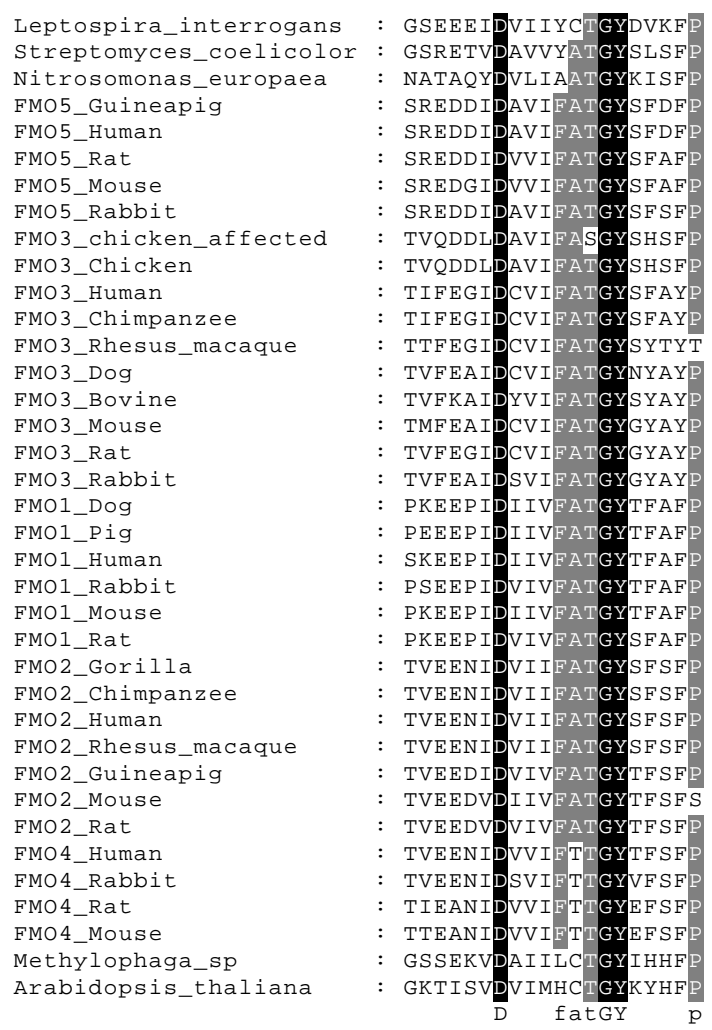

\section{Johtopäätökset}

Tässä tutkimuksessa on osoitettu, että kananmunien kalanhajun syy johtuu geenivirheestä FMO3 geenissä. Lisäksi geeni on pystytty luotettavasti paikallistamaan kromosomiin 8. Edelleen, geenivirheen testaamiseksi on kehitetty luotettava ja nopea geenitesti.

Alunperin harmiton hajun aiheuttava geenimuunnos lienee syntynyt kauan aikaa sitten yksilössä, josta useimmat ruskeat munijalinjat polveutuvat. Hajugeeni on näin päässyt yleistymään ruskeissa kanoissa (taulukko 1). Valkoisista munijalinjoista muutosta ei olla tavattu.

Tutkimustulosten perusteella geenivirheen ei ole havaittu vaikuttavan mihinkään muihin tuotanto- tai laatuominaisuuksiin hajua lukuunottamatta.

Geenitesti mahdollistaa sen esimerkiksi, että luomutuottajat eivät ole enää sidottuja käyttämään eri tuotantohybrideille tiettyä rehuja, vaan ruskeillekin munijakanoille voidaan syöttää rypsipitoista rehua. Jos luomutuotannossa siirrytään 100 \%:sti luomurehuruokintaan, on kotimainen rypsi- ja rapsirehu varteenotettava raaka-aine munijakanojen valkuaistarpeen tyydyttämisessä, erityisesti rikkipitoisten aminohappojen lähteenä.

\section{Kirjallisuus}

M. Honkatukia, K. Reese, R. Preisinger, M. Tuiskula-Haavisto, S. Weigend, J. Roito, A. Mäki-Tanila and J. Vilkki. 2005. Fishy taint in chicken eggs is associated with a substitution within a conserved motif of the FMO3 gene. Genomics 86: 225-232.

M. Honkatukia. 2005. Geenitestistä apua kananmunien kalanhajuiseen laatuongelmaan. Suomen siipikarja 3/05. 